\title{
Nutritional quality of forages used by elk in northern Idaho
}

\author{
MATHEW W. ALLDREDGE, JAMES M. PEEK, AND WILLIAM A. WALL
}

Authors are Ph.D. candidate, Biomathematics Program, Statistics Department, North Carolina State University, Raleigh, N.C. 27695; professor, Department of Fish and Wildlife Resources, University of Idaho, Moscow, Ida. 83844; and Wildlife Biologist, Safari Club International, Herndon, Virg. 20170. At the time of the research the senior author was Research Assistant, Department of Fish \& Wildlife Resources, University of Idaho, Moscow, Ida.

\begin{abstract}
The nutritional quality (digestible energy, crude protein, and minerals) of 7 known elk (Cervus elaphus Linnaeus) forages was assessed at 4 different time periods from May to November. Species evaluated were elk sedge (Carex geyeri Boott), Kentucky bluegrass (Poa pratensis Linnaeus), western goldthread (Coptis occidentalis Nuttall), clover (Trifolium repens Linnaeus), serviceberry (Amelanchier alnifolia Nuttall), redstem ceanothus (Ceanothus sanguineus Pursh), and Scouler willow (Salix scouleriana Barratt). Mineral concentrations generally met estimated requirements for elk in all seasons, except sodium remained below requirements in all seasons. Crude protein in most plant species sampled was adequate for adult gravid or lactating cows throughout the year, although concentrations in graminoids fell below requirements during August. Forage provided adequate digestible energy for gravid or lactating cows only during May, indicating potential deficiencies in summer and autumn. Elk must be selective of plant parts, plant taxa, and foraging habitat to gain adequate nutrition. In this area, summer and fall forage quality may be critical to lactating cow elk.
\end{abstract}

Key Words: Elk, Cervus elaphus, forage quality, nutrition, Idaho

Industrial forests in northern Idaho managed primarily for timber production contain substantial populations of elk. These forests contain a mixture of age classes of trees in a diverse mosaic of successional patterns. However, they do not provide large blocks of mature timber for security cover and road densities are high, causing them to fall outside of the suitable criteria for elk habitat developed by Leege (1984).

Elk presumably select habitats that have high quality, abundant forage, or provide cover (Patton 1974, Edge et al. 1988, Thomas et al. 1979). Nutritional quality of available forages may change with phenological stage, between vegetation classes, aspect, and overstory structure (Irwin and Peek 1979). Nutrition is assumed to be a primary factor influencing elk distribution, abundance,

Authors wish to thank J. G. Cook, P. J. Heglund, R. K. Steinhorst , and C. J. Williams for their advice. K.L. Launchbaugh extended use of her lab for the nutritional analysis. J. Scott and B. Knapton provided invaluable field assistance Research was funded by Potlatch Corporation, Rocky Mountain Elk Foundation, and the University of Idaho. This is University of Idaho, College of Natural Resources Journal Series Paper Number 956.

Manuscript accepted 7 Sept. 01

\section{Resumen}

Se evaluó la calidad nutricional (energía digestible, proteína cruda y minerales) de 7 especies forrajes que se sabe que el alce (Cervus elaphus Linnaeus) las consume, la evaluación se realizó en 4 diferentes periodos de tiempo de Mayo a Noviembre. Las especies evaluadas fueron: "Elk sedge" (Carex geyeri Boott), "Kentucky bluegrass" (Poa pratensis Linnaeus), "Western goldthread" (Coptis occidentalis Nuttall), "Clover" (Trifolium repens Linnaeus), "Serviceberry" (Amelanchier alnifolia Nuttall), "Redstem ceanothus" (Ceanothus sanguineus Pursh) y "Scouler willow" (Salix scouleriana Barratt). Las concentraciones de minerales generalmente satisfacen los requerimientos estimados para el alce en todas las estaciones, excepto sodio el cual permanece abajo de los requerimientos en todas las estaciones. A través de todo el año la proteína cruda de la mayoría de las especies de plantas muestreadas fue adecuada para las hembras preñadas o lactantes, sin embargo, en Agosto, las concentraciones de proteína cruda de las gramíneas cayó por abajo de los requerimientos. El forraje proveyó de energía digestible adecuada para las hembras adultas preñadas o lactantes solo en Mayo, indicando deficiencias potenciales en verano y otoño. Para tener una nutrición adecuada el alce debe ser selectivo de las partes de la planta que consume, el género de planta y el hábitat de forrajeo. En esta área la calidad del forraje en verano y otoño puede ser critica para las hembras lactantes de alce.

and productivity (Cook in press). However, few studies have described forage quality and attempt to relate this to the nutritional levels that elk experience.

We examined nutritional quality of primary elk forages in an industrial forest. We build on the substantial number of elk habitat use investigations in northern Idaho showing the importance of seral shrub communities as foraging areas. Substantial knowledge of food habits and responses of forage plants to logging and burning is also available for this area to pursue the analyses. Specific objectives were to (1) assess the variability in digestible energy, crude protein, and mineral concentrations of known elk forages across seasons and topographical aspect; (2) determine seasonal trend in nutritional quality by species and vegetation class; and (3) compare nutritional quality of representative forage species with the daily nutritional requirements of elk.

\section{Study Area}

The study area was located west of the Dworshak Reservoir in the North Fork of the Clearwater River drainage, in Clearwater County, Ida. $\left(45^{\circ} \mathrm{N}, 116.15^{\circ} \mathrm{W}\right)$. Mild summers and long-cold 
winters characterize the climate in the area (Hansen et al. 1989). Annual precipitation is $93.6 \mathrm{~cm}$ with the majority falling as snow from November through February. Western Red Cedar-Pachistima (Thuja plicata Donn-Pachistima myrsinites Rafinesque) habitat type dominates the area (Daubenmire and Daubenmire 1968). Alldredge et al. (2001), Cooper et al. (1987), Crookston and Stage (1999), Irwin and Peek (1979), Moeur (1985), and Stage (1973) have described the successional patterns, species composition, and productivity of this habitat type in northern Idaho.

Logging since the 1920's has created a variety of seral stands from clearcuts to closed-canopy forests. Approximately $14 \%$ of the area is a recently cut, grass/low shrub community. Kentucky bluegrass (Poa pratensis L.), elk sedge (Carex geyeri Boott), pearly everlasting (Anaphalis margaritacea L.), fireweed (Epilobium angustifoliums L), senecios (Senecio triangularis Hooker), pentstemons (Pentstemon spp Mitch.), pinegrass (Calamagrostis rubescens Buck.), wild strawberry (Fragaria vesca L.) were common forbs and graminoids. Clover (Trifolium repens L.) commonly occurred along access routes that had been reseeded. A tall shrub/grass community occupied $36 \%$ of the study area. Mountain maple (Acer glabrum Torrey), redstem ceanothus (Ceanothus sanguineus Pursh), serviceberry (Amelanchier alnifolia Nuttall), and Sitka alder (Alnus sinuata Rydberg) were common shrubs, with similar graminoids and forbs. Open-canopy conifer communities comprised $21 \%$ of the area, with Douglas fir (Pseudotsuga menziesii Franco) being the most common tree. Understories were more sparse, and shade tolerant species including mountain maple, thimbleberry (Rubus parviflorus Nuttall), Scouler willow (Salix scouleriana Barratt), pachistima, huckleberries (Vaccinium membranaceum Douglas, $V$. globulare Rydberg), and menziesia (Menziesia ferruginia Smith ) were common. Common understory species included western goldthread (Coptis occidentalis Nuttall), twinflower (Linneaea borealis L.), Solomon seal (Smilacina stellata L.), and bedstraw (Gallium triflorum Michx). Closed-canopy forests containing very sparse understories of shade-tolerants comprised $29 \%$ of the area.

Potlatch Corporation managed $40.6 \%$, Idaho Department of Lands $32.1 \%$, and U.S. Forest Service $18.8 \%$ of the area. The study area received over 30,000 hunterdays use in recent years (Idaho Department of Fish and Game 1999). Alldredge (1999) reported that elk foraged in areas that had been logged within the past 20 years, except during the rifle hunting season, when they switched to mature conifer cover, confirming the general pattern observed by Hash (1973), Hershey and Leege (1984), Irwin and Peek (1983b, McLean (1972), and Unsworth et al. (1998) in northern Idaho.

\section{Methods}

\section{Collections}

We selected graminoids, forbs, and shrubs known to be important in the elk diet in the area (Irwin and Peek 1983a, Kingery et al. 1996, Leege 1969, Leege and Godbolt 1985, Nelson and Leege 1982, Young and Robinette 1939). Elk sedge, Kentucky bluegrass, western goldthread, clover, serviceberry, redstem ceanothus, and Scouler willow were collected to represent the variety of species used by elk and abundant in the study area.

Collections for all of these species were made on 3 sites in 6 areas in mid-June, mid-August, and mid-November, 1997-1998 and May 1998. Clover became completely desiccated and unavailable in November. Plants were collected on north and south aspects to represent different light and moisture conditions, in the cedarpachistima habitat type.

Current year's growth of shrubs, and above-ground portions of graminoids and forbs were collected for analysis. The entire twig of current year's growth, including leaves except in November was collected for shrubs, and graminoids and forbs were clipped to within $1 \mathrm{~cm}$ of the ground. Approximately $200 \mathrm{~g}$ per species per site were collected. Samples also consisted of collections from multiple plants to account for variation between plants.

\section{Forage Analysis}

Samples were oven-dried at $40^{\circ} \mathrm{C}$ for 48 hours, ground with a Wiley Mill through a $1 \mathrm{~mm}$ screen, and stored until analysis. This temperature was selected to ensure that fermentable carbohydrates were retained, at the risk of reduction of cell solubles (Wolf and Carson 1973). Analyses included in-vitro-dry-matterdigestibility (IVDMD), gross energy con- tent, and macro- and micro-element concentrations.

The IVDMD was determined using the Tilley and Terry (1963) technique as modified by Pearson (1970). Ancom filter bags were used to contain the material during fermentation. In-vitro-dry-matter-digestion was terminated after 48 hours for all trials. To reduce variability in the lab procedure, rumen inoculum was obtained from a single Hereford cow maintained on a constant alfalfa diet and all analyses were done within a 2 month period.

Estimates of gross energy were determined for 2 samples for each species within each time period using bomb calorimetry. Digestible energy was determined for all samples collected by approximating digestible energy as the product of digestibility and gross energy (Hobbs et al. 1982, Robbins 1983). Crude protein was estimated as 6.25 times the percent nitrogen content (A.O.A.C. 1984).

The organic and mineral composition of the 7 selected forage species was estimated across seasons and years. Organic constituents of carbon $(\mathrm{C})$, nitrogen $(\mathrm{N})$, and sulfur (S), were determined using a combustion technique (McGeehan and Naylor 1988). Atomic emission spectroscopy (Anderson 1996) was used to determine concentrations of aluminum ( $\mathrm{Al})$, cadmium $(\mathrm{Cd})$, calcium $(\mathrm{Ca})$, chromium $(\mathrm{Cr})$, cobalt (Co), copper $(\mathrm{Cu})$, iron $(\mathrm{Fe})$, lead $(\mathrm{Pb})$, molybdenum $(\mathrm{Mo})$, potassium $(\mathrm{K})$, phosphorus (P), magnesium (Mg), manganese $(\mathrm{Mn})$, sodium $(\mathrm{Na})$, nickel $(\mathrm{Ni})$, sulfur $(\mathrm{S})$, vanadium $(\mathrm{V})$, and zinc $(\mathrm{Zn})$.

We used multiple analysis of variance (MANOVA) to assess the variability in nutrient quality by aspect, time, species, and vegetation class. Vegetation class (graminoids, forbs, shrubs) was examined because these differences could affect cover type use. Trends in nutritional quality of each forage species were examined to determine if they met the requirements of elk. Crude protein and digestible energy concentrations by species and vegetation class were compared to estimated daily requirements of an elk (Cook in press), across time periods, using a t test. Estimates of digestible energy and crude protein were based on an adult cow, gravid in spring and lactating through mid-autumn, with average consumption rates, daily activities, and metabolic demands. Mineral concentrations were also compared to mineral requirements for cattle (National Research Council 1996), using a t-test. 


\section{Results}

A total of 114 and 160 vegetation samples were collected during 1997 and 1998. Seasonal collections were made within 2 days of the same date each year. No significant differences in energy, mineral concentrations or protein were related to aspect.

\section{Minerals}

Mineral concentrations in all species were variable with no predictable seasonal patterns (Table 1). Molybdenum, Co, and $\mathrm{Ni}$ concentrations were below detectable limits. Significant differences were detected $(\mathrm{P}<0.001)$ for time*species and time*vegetation class interactions, indicating a high degree of variability in mineral concentrations. Forage species provided sufficient concentrations of required minerals above levels necessary to meet animal requirements for all seasons $(t>2.92$, $\mathrm{P}<0.02$ ), with the exception of $\mathrm{Na}$. The highest $\mathrm{Na}$ level in any forage species was $91 \mu \mathrm{g} / \mathrm{g}$, well below estimated minimum $\mathrm{Na}$ requirement for cattle of $600 \mu \mathrm{g} / \mathrm{g}$.

Some forage species, including $\mathrm{Mg}$ and $\mathrm{K}$, provided concentrations of some minerals above the maximum tolerable limits during certain time periods. No mineral exceeded the tolerable limits for elk across all forage species during any single time period. Elements toxic to animals, such as $\mathrm{Cd}$ and $\mathrm{Pb}$, were present at low levels throughout all seasons in all forage species.

\section{Crude Protein}

Crude protein levels in all species declined from May through November (Table 2). In May crude protein concentrations in all 3 shrubs and clover were over $24 \%$, higher than other species across all collection periods, except western goldthread in November. Crude protein in western goldthread was lower than all other species early in the year but smaller declines throughout the year relative to other species resulted in high levels in November.

A similar pattern was observed in levels of crude protein by vegetation class (Table 2 ). Protein concentrations in graminoids were lower than in other vegetation classes. Shrubs had higher levels than forbs in May and June, were similar in August, and lower than forbs in November. Significant differences in crude protein concentrations were detected within species and vegetation classes between collection periods ( $\mathrm{P}$ $<0.05$, Table 2).

All species provided adequate protein for elk in May, but only redstem ceanothus, Scouler willow, serviceberry, and clover met requirements in June. By August crude protein of redstem ceanothus and clover exceeded requirements, as did western goldthread in November. Protein levels in forbs and shrubs met requirements for elk in all seasons except for shrubs in November. Levels of protein in graminoids met elk requirements only in May. In August crude protein levels in graminoids, elk sedge, and Kentucky bluegrass were significantly lower than elk requirements $(t$ $>3.4, \mathrm{P}=0.01, \mathrm{P}=0.01$, and $\mathrm{P}<0.0001$, respectively). Crude protein concentrations in Kentucky bluegrass and redstem ceanothus were significantly below requirements during November $(\mathrm{t}>2.83, \mathrm{P}<$ 0.0001 and $\mathrm{P}=0.04$, respectively).

\section{Digestible Energy}

Digestible energy declined from May through November, with some species increasing from August to November (Table 3). Western goldthread showed the largest increase in digestible energy between August and November, but Scouler willow, redstem ceanothus, and serviceberry also increased between these times. Western goldthread had the highest levels of digestible energy for all seasons. Scouler willow had the lowest levels for all periods except November, where it had one of the highest concentrations. Elk sedge and Kentucky bluegrass had the

Table 1. High and low mineral concentrations found in forage species and estimated elk requirements (Cook in press, National Research Council 1984) of macro and micro elements (bdl = below detectable levels, and N/A = not available). Concentrations reported in $\mu$ g/g. Values are averages of mineral concentrations within a given time period. MANOVA detected significant differences $(P<0.001)$ for $*$ timespecies and time* vegetation class interactions. All centrations of required minerals except $\mathrm{Na}$ were above required levels for all seasons $(t>2.92$, $\mathrm{P}<0.02)$. Co, Mo, and $\mathrm{Ni}$ concentrations were below detectable limits.

\begin{tabular}{|c|c|c|c|c|c|c|c|c|}
\hline & Required & Clover & Goldthread & Elk sedge & Bluegrass & Redstem & Serviceberry & Scouler Willow \\
\hline & & $--\cdots$ & $-\cdots$ & $---2-0$ & $-(\mu \mathrm{g} / \mathrm{g})--$ & $--1---1$ & $\ldots$. & $\cdots$ \\
\hline Al & N/A & $52-338$ & $66-302$ & $65-505$ & $72-255$ & $71-191$ & $25-308$ & $201-715$ \\
\hline $\mathrm{Cd}$ & N/A & $0.2-0.5$ & $0.1-0.3$ & $0.04-0.9$ & $0.2-1.7$ & $0.1-0.4$ & $0.1-1.3$ & $0.1-1.3$ \\
\hline $\mathrm{Ca}$ & $1600-5800$ & $9,683-13,780$ & $2,467-13,750$ & $5,608-11,367$ & $2,983-10,217$ & $7,167-13,200$ & $3,450-8,950$ & $12,000-14,283$ \\
\hline $\mathrm{Cr}$ & N/A & Bdl-0.3 & $0.1-1.0$ & $0.1-0.8$ & $0.3-0.8$ & $0.1-0.5$ & bdl-0.4 & $0.5-0.7$ \\
\hline $\mathrm{Co}$ & $0.07-0.11$ & bdl $^{\mathrm{c}}-0.4$ & $\mathrm{bdl}^{\mathrm{c}}-0.2$ & $\mathrm{bdl}^{\mathrm{c}}-0.2$ & $0.1-2.8$ & $b d l^{c}-0.1$ & $b^{b} l^{c}-0.2$ & $0.6-1.7$ \\
\hline $\mathrm{Cu}$ & 4-10 & $5.0-12.9$ & $6.0-7.1$ & $4.6-7.2$ & $4.0-9.8$ & $3.6^{\mathrm{c}}-9.6$ & $6.0-8.1$ & $6.5-12.7$ \\
\hline $\mathrm{Fe}$ & $50-100$ & $111-220$ & $113-321$ & $111-230$ & $98-163$ & $107-195$ & $10^{\mathrm{c}}-110$ & $29-201$ \\
\hline $\mathrm{Pb}$ & N/A & $6-56$ & $11.5-234$ & $17-150$ & $29-245$ & $1.1-39$ & $3.3-111$ & $0.9-19$ \\
\hline $\mathrm{Mg}$ & $500-2500$ & $2,500-3,708$ & $1,562-3,267$ & $1,228-2,217$ & $1,267-2,717$ & $1,231-2,842$ & $1,333-1,650$ & $2,100-4,467^{b}$ \\
\hline $\mathrm{Mn}$ & $20-50$ & $241-414$ & $78-195$ & $205-493$ & $300-413$ & $748-143$ & $143-453$ & $97-302$ \\
\hline Mo & $6^{\mathrm{a}}$ & Bdl-0.2 & $0.3-1.1$ & Bdl-1.3 & bdl & bdl-0.4 & bdl-2.0 & bdl- -0.2 \\
\hline $\mathrm{Ni}$ & N/A & $0.06-1.8$ & $0.1-1.3$ & $0.3-2.4$ & $0.2-4.1$ & bdl-1.3 & $0.2-3.5$ & $1.6-3.8$ \\
\hline $\mathrm{K}$ & $5000-7000$ & $9,867-26,750$ & $11,408-31,500^{\mathrm{b}}$ & $11,408-19,833$ & $7,308-16,417$ & $9,392-20,083$ & $5,217-31,500^{b}$ & $10,092-32,833^{b}$ \\
\hline $\mathrm{P}$ & $1700-3900$ & $3,267-5,633$ & $2,375-3,817$ & $1,260^{\mathrm{c}}-4,525$ & $970^{c}-5,258$ & $1,273^{c}-3,250$ & $1,633^{\mathrm{c}}-2,733$ & $1,767-3,000$ \\
\hline $\mathrm{Na}$ & $600-1000$ & $19^{c}-45^{c}$ & $32^{c}-92^{c}$ & $30^{\mathrm{c}}-71^{\mathrm{c}}$ & $27^{c}-63^{c}$ & $25^{\mathrm{c}}-50^{\mathrm{c}}$ & $27^{c}-39^{c}$ & $20^{\mathrm{c}}-81^{\mathrm{c}}$ \\
\hline$S$ & $800-1500$ & $857-2,142$ & $1,588-2,258$ & $1,143-2,358$ & $913-3,133$ & $880-1,983$ & $663^{c}-2,075$ & $1,382-2,083$ \\
\hline $\mathrm{V}$ & N/A & $0.1-1.3$ & $0.3-2.3$ & $0.1-2.7$ & $0.1-1.8$ & $0.2-2.3$ & $0.5-2.5$ & $0.4-3.5$ \\
\hline $\mathrm{Zn}$ & $20-40$ & $37-58$ & $28-100$ & $27-39$ & $21-136$ & $18^{\mathrm{c}}-73$ & $22-42$ & $30-109$ \\
\hline
\end{tabular}

a no specified requirement, but a maximum tolerable value was known.

$b$ concentrations of the given element exceed the maximum tolerable limit.

${ }^{c}$ concentrations of the given element do not meet the minimum requirements. 
Table 2. Crude protein concentrations (percent) for all species and vegetation classes across all time periods, with corresponding $\mathbf{9 5 \%}$ confidence intervals. Required levels from Cook (in press).

\begin{tabular}{|c|c|c|c|c|}
\hline $\begin{array}{l}\text { Species/ } \\
\text { Vegetation Class }\end{array}$ & May & June & August & November \\
\hline & \multicolumn{4}{|c|}{ 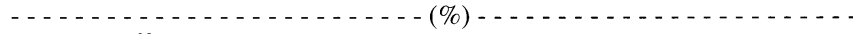 } \\
\hline Forbs & $18.7 \pm 13.2^{\mathrm{N}}$ & $15.8 \pm 10.7$ & $12.5 \pm 5.3$ & $8.7 \pm 1.8$ \\
\hline Clover & $24.3 \pm 2.6^{\mathrm{A}}$ & $19.7 \pm 8.1$ & $14.3 \pm 3.5$ & $\mathrm{~N} / \mathrm{A}$ \\
\hline Western goldthread & $13.0 \pm 3.9$ & $11.8 \pm 6.2$ & $11.0 \pm 5.0$ & $8.7 \pm 1.8$ \\
\hline Graminoids & $17.8 \pm 6.5^{\mathrm{A}, \mathrm{N}}$ & $11.6 \pm 6.9$ & $5.83 \pm 3.4$ & $4.7 \pm 3.8$ \\
\hline Elk sedge & $16.0 \pm 4.7^{\mathrm{A}, \mathrm{N}}$ & $11.2 \pm 7.2$ & $6.8 \pm 3.4$ & $5.9 \pm 3.6$ \\
\hline Kentucky bluegrass & $19.7 \pm 6.7^{\mathrm{A}, \mathrm{N}}$ & $12.0 \pm 7.5$ & $4.9 \pm 2.4$ & $3.5 \pm 2.1$ \\
\hline Shrubs & $26.5 \pm 8.3^{\mathrm{N}}$ & $20.5 \pm 9.2^{\mathrm{N}}$ & $12.6 \pm 7.0$ & $6.1 \pm 1.8$ \\
\hline Redstem ceanothus & $29.5 \pm 6.5^{\mathrm{A}, \mathrm{N}}$ & $23.9 \pm 5.8^{\mathrm{N}}$ & $15.1 \pm 6.0$ & $5.6 \pm 1.3$ \\
\hline Scouler willow & $24.2 \pm 8.0^{\mathrm{A}, \mathrm{N}}$ & $19.8 \pm 6.7^{\mathrm{N}}$ & $11.2 \pm 3.5$ & $6.8 \pm 1.24$ \\
\hline Serviceberry & $25.9 \pm 10.3^{\mathrm{N}}$ & $14.9 \pm 9.8$ & $11.3 \pm 8.8$ & $6.1 \pm 2.2$ \\
\hline Requirements & 7.5 & 15 & 12 & 7.5 \\
\hline
\end{tabular}

${ }^{\mathrm{A}}$ Estimate significantly different than estimate in August $(\mathrm{P}<0.05)$

${ }^{N}$ Estimate significantly different than estimate in November $(\mathrm{P}<0.05)$. lowest levels of digestible energy of all species in November. Levels of digestible energy were more similar for all species during August. Significant differences in digestible energy were detected within species between collection periods $(\mathrm{P}<$ 0.05) (Table 3).

Seasonal trends in digestible energy levels by vegetation class were similar (Table 3 ). Graminoids declined from 3,100 $\mathrm{kcals} / \mathrm{kg}$ to $1,450 \mathrm{kcals} / \mathrm{kg}$ between May and November. Digestible energy of shrubs was highest in May at 3,200 $\mathrm{kcals} / \mathrm{kg}$, lowest in August at just over $1,800 \mathrm{kcals} / \mathrm{kg}$, and moderate $(2,000$ $\mathrm{kcals} / \mathrm{kg}$ ) in November. Forbs also declined through the seasons from almost $3,500 \mathrm{kcals} / \mathrm{kg}$ in May to slightly over
$1,900 \mathrm{kcals} / \mathrm{kg}$ in August. Western goldthread, the only forb measured during digestible energy. Between mid-June and mid-August, digestible energy content in graminoids fell below shrubs. Significant differences in digestible energy concentrations were detected within vegetation classes between collection periods $(\mathrm{P}<$ 0.05 , Table 3 ).

All species and vegetation classes met estimated digestible energy requirements of elk during May. Digestible energy levels for all species and vegetation classes were significantly below requirements $(\mathrm{t}>$ $3.61, \mathrm{P}<0.05$ ) during June, August, and November, except for western goldthread in November. November, contained about 3,300 kcals/kg

Table 3. Digestible energy levels (Kcal/kg of forage) for all species and vegetation classes across all time periods, with corresponding $95 \%$ confidence intervals. Required levels from Cook (in press).

\begin{tabular}{|c|c|c|c|c|}
\hline $\begin{array}{l}\text { Species/ } \\
\text { Vegetation Class }\end{array}$ & May & June & August & November \\
\hline & \multicolumn{4}{|c|}{ 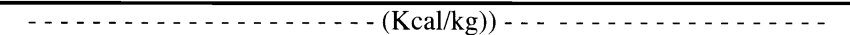 } \\
\hline Forbs & $3,454 \pm 182^{\mathrm{J}, \mathrm{A}, \mathrm{N}}$ & $2,385 \pm 177^{\mathrm{A}, \mathrm{N}}$ & $1,910 \pm 285^{\mathrm{N}}$ & $3,286 \pm 42$ \\
\hline Clover & $3,236 \pm 195^{\mathrm{J}, \mathrm{A}}$ & $2,146 \pm 184$ & $1,673 \pm 473$ & $\mathrm{~N} / \mathrm{A}$ \\
\hline Western goldthread & $3,672 \pm 188^{\mathrm{J}, \mathrm{A}, \mathrm{N}}$ & $2,567 \pm 105^{\mathrm{A}, \mathrm{N}}$ & $2,147 \pm 377^{\mathrm{N}}$ & $3,286 \pm 42$ \\
\hline Graminoids & $3,141 \pm 120^{\mathrm{J}, \mathrm{A}, \mathrm{N}}$ & $2,337 \pm 105^{\mathrm{A}, \mathrm{N}}$ & $1,681 \pm 144$ & $1,456 \pm 136$ \\
\hline Elk sedge & $2,980 \pm 143^{\mathrm{J}, \mathrm{A}, \mathrm{N}}$ & $2,298 \pm 139^{\mathrm{A}, \mathrm{N}}$ & $1,761 \pm 175$ & $1,578 \pm 04$ \\
\hline Kentucky bluegrass & $3,301 \pm 57^{\mathrm{J}, \mathrm{A}, \mathrm{N}}$ & $2,375 \pm 160^{\mathrm{A}, \mathrm{N}}$ & $1,601 \pm 226$ & $1,334 \pm 160$ \\
\hline Shrubs & $3,195 \pm 246^{\mathrm{J}, \mathrm{A}, \mathrm{N}}$ & $1,915 \pm 156$ & $1,779 \pm 187$ & $2,007 \pm 76$ \\
\hline Redstem ceanothus & $3,497 \pm 146^{\mathrm{J}, \mathrm{A}, \mathrm{N}}$ & $2,013 \pm 181$ & $1,740 \pm 223$ & $1,897 \pm 114$ \\
\hline Scouler willow & $2,601 \pm 423^{J, A, N}$ & $1,565 \pm 261^{\mathrm{N}}$ & $1,623 \pm 317$ & $2,073 \pm 154$ \\
\hline Serviceberry & $3,488 \pm 93^{\mathrm{J}, \mathrm{A}, \mathrm{N}}$ & $1,973 \pm 129$ & $2,092 \pm 404$ & $2,049 \pm 109$ \\
\hline Requirements & 2,200 & 3,000 & 2,700 & 2,400 \\
\hline
\end{tabular}

${ }^{\mathrm{J}}$ Estimate significantly different than estimate in June $(\mathrm{P}<0.05)$

${ }^{A}$ Estimate significantly different than estimate in August $(\mathrm{P}<0.05)$

${ }^{\mathrm{N}}$ Estimate significantly different than estimate in November $(\mathrm{P}<0.05)$.

\section{Discussion}

The high degree of variability in mineral concentrations observed in this study might be expected. Differences between vegetation classes are typical due to different cell-wall components (Short 1981). Other studies have documented a high degree of variability in plant mineral concentrations associated with soil type, precipitation, and weather conditions (Poole et al. 1989, Beaver 1999). Spring weather conditions can affect the timing of growth initiation. This, along with subsequent weather conditions could affect the phenological stage of plants throughout the growing season. Favorable growing conditions may be conducive to greater mineral absorption (Beaver 1999).

The importance of minerals to the proper biological function of animals is well recognized (Underwood 1977, Robbins 1983, Van Soest 1994), but often neglected in studies of large herbivores (Cook in press). Results from this study indicate that elk mineral requirements are generally provided for. Mixing of forage species probably compensates for deficiencies and for concentrations in certain species that are too high.

Sodium, which averaged only $1 / 10$ or less of the daily nutritional requirements (estimates for beef cattle), is the cation of the extracellular environment, it is important for regulation of body fluid volume and osmolarity, acid-base balance and tissue $\mathrm{pH}$, muscle contraction, and nerve impulse transmission (Robbins 1983). Thus, without sufficient amounts of sodium, elk growth and reproduction could be depressed. However, elk may be obtaining sodium from other sources than forage consumption, such as mineral licks and water (Weeks and Kirkpatrick 1976, Robbins 1983).

Toxic elements were also found in the forage analyzed. Detrimental effects of toxic elements, such as lead and cadmium, are related to the magnitude of the concentration within the body. Cadmium levels appear quite low and are similar to levels that are in domestic animal feeds (Underwood 1977). However, lead concentrations were much higher and were similar to levels reported from pastures rich in lead or areas near lead mines (Underwood 1977). Whether these levels would produce a toxic effect was not determined.

Percent crude protein in forage species 
steadily declined from May through November, a commonly reported pattern (Cook in press). We also found that shrubs had higher concentrations of crude protein than graminoids. This may be an area-specific relationship as Urness et al. (1983) reported higher levels of protein in graminoids than shrubs, but others have reported the opposite (Everitt and Gonzalez 1981, Meyer et al. 1984). Hobbs et al. (1981) reported that grasses typically had lower concentrations of crude protein than shrubs during winter. However, our results indicate that crude protein in graminoids is significantly lower than in shrubs during August, but only slightly lower in November.

During summer, elk forage in open areas where abundant new-growth provides ample nutrients (Martinka 1969, Edge et al. 1988, Leege 1984). McLean (1972) and Hash (1973) reported elk using shrubfields throughout late summer and fall in northern Idaho. Movement to security areas of closed-canopy cover types during hunting seasons is evident in other areas as well (Morgantini and Hudson 1980, Unsworth and Kuck 1991, Hurley 1994).

Estimates of crude protein levels from May through November generally provided for the requirements of elk. Small deficiencies could be overcome via selective foraging. For example, elk could select leaves and terminal ends of twigs to overcome small deficiencies (Blair and Epps 1967, Dietz 1972). However, the higher the level of selective foraging to meet requirements results in a greater proportion of total forage that is "unavailable." Significant deficiencies, such as those observed for all graminoids in August, might not be overcome by diet selection.

By August, crude protein of graminoids was so low that losses of endogenous body protein associated with digesting them would equal or exceed any gain (Hobbs et al. 1982). The crude protein deficiencies we observed for graminoids in August indicate that elk could not restrict their diet to them and maintain endogenous body protein. Maintenance of dietary mixes is a means of achieving energy and protein requirements (Hobbs et al. 1981, Otsyina et al. 1982). Low crude protein levels in graminoids coincide with the period when elk have shifted from grass/low shrub areas to areas dominated by shrubs (Alldredge 1999).

Digestible energy levels of forage declined steadily from May through
November, failed to provide for elk requirements after May, and were most deficient in graminoids after mid-summer. These patterns suggest elk should shift from grass/low shrub areas to areas with greater shrub development as seasons progress. In Colorado grasses provided more digestible energy on winter range than shrubs (Hobbs et al. 1981). However, our results for November suggest that shrubs provide more digestible energy during this period.

Estimates of digestible energy indicate that requirements of gravid cow elk are provided for in May, but moderate to severe deficiencies exist for lactating cow elk during the entire summer. Studies with captive elk indicate that lactating cow elk cannot be maintained (J.G. Cook personal communication) nor can elk calves grow (Cook et al. 1996) on diets with the low levels of digestible energy we report. Digestible energy is commonly a limiting component of ungulate diets from midsummer through winter on many western large-ungulate ranges (Cook, in press, Parker et al. 1999). Loss of condition on winter range is expected as nutritional levels of winter forage decline below the requirements for maintenance (Hobbs et al. 1981, Cook in press).

Nutritional deficiencies can have serious effects on the reproductive capabilities of elk. Thorne et al. (1976) related poor condition to low birth weight, which resulted in a low probability of calf survival. Poor condition has resulted in delayed ovulation and breeding (Verme 1969), failure to ovulate, resorption of ovum, and failure to conceive (Trainer 1971). Failure to breed as a result of poor condition was reported for caribou (Rangifer tarandus, Cameron 1994) and elk (Trainer 1971, Cook 2000). Pregnancy rates of elk as low as $70 \%$ in some areas of Idaho (Gratson and Zager 1999) and 55\% in western Oregon (Stussy 1993) have been reported. These low pregnancy rates are probably due to inadequate nutrition on summer and autumn ranges. Low levels of digestible energy reported in our study could result in reproductive pauses, slow calf growth over summer and autumn, and increased winter mortality because condition in autumn may be relatively poor, especially as the effects of low nutrition accumulate across years.

Foraging efficiency is an important factor influencing cover type use (Collins et al. 1978, Irwin and Peek 1983b). Both quantity and quality of forage are factors influencing cover type use patterns
(Hanley et al. 1989). Several studies have demonstrated that both natural and manmade openings in forest canopies result in dramatic increases in forage production (Patton 1974, Lyon and Jensen 1980, Riggs et al. 1990). Maximum annual shrub biomass productivity occurs between 7 and 14 years after overstory removal (Alldredge 1999) and total shrub biomass was greatest 10 to 14 years following harvests within the cedar-hemlock zone of northern Idaho (Irwin and Peek 1979). Changes in habitat use from early summer to fall indicate that forage quality may be a factor driving habitat selection as areas used in both periods have large quantities of forage.

Many studies indicate that elk habitat use should switch during the fall to areas with conifer over-stories because vegetation in these areas remains succulent (Stehn 1973, Biggins 1975, Schoen 1977, Irwin and Peek 1983b, Wisdom and Cook 2000). However, forage quantity in conifer stands is very low. Graminoids and forbs are rare and total annual shrub productivity, including unpalatable species, is only $50 \mathrm{~kg} / \mathrm{ha}, 5$ to 10 times lower than early successional areas (Alldredge 2001). Such low forage biomass may limit foraging efficiency as instantaneous intake rates decrease and travel rates are elevated (Wickstrom et al. 1984). Low foraging efficiency may account for avoidance of conifer- dominated habitats as key foraging areas (Collins and Urness 1983) because lactating cow elk would not be able to consume sufficient forage to meet daily nutritional requirements (Cook in press).

\section{Management Implications}

Our nutrition data indicate that elk forages provide adequate levels of minerals and probably protein over the summer and autumn. However, digestible energy deficiencies over an extended period of time warrants concern, especially in relation to potential effects on herd productivity. Our data only provide a measure of the digestible energy available to elk, and does not indicate actual digestible energy content of diets. Thus, conclusions about the effects on their nutritional condition and productivity are avoided. At the least, the data indicate that elk must be highly selective of plant parts, plant taxa, and habitats where they forage, if they are to 
achieve adequate digestible energy intake. Therefore, we speculate that much of the forage available to them is of little value, and "carrying capacity" is probably considerably lower than would be predicted based only on forage biomass. Our data also suggest a nutritional environment that is marginal in its ability to provide for the summer-fall digestible energy needs of cow-calf pairs. We would predict relatively strong density-dependent relations in such an environment, because a potentially small portion of the forage base apparently is actually of value to elk. Further, we would predict that under these marginal conditions that landscape-scale forest management practices that influence forage quality and quantity will have substantial long-term influences on these elk. Although causes are unknown, elk herds of the Clearwater basin in north-central Idaho have experienced declines in calf recruitment and subsequently declines in herd size of about $25 \%$ over the last decade (Gratson and Zager 1999). Our data suggest that nutrition, perhaps via density dependent mechanisms, should be suspected as a potential contributor to these declines.

Our data support the contention that a diversity of habitats providing forages that vary in nutritional levels through time is an important factor in maintaining highquality habitat for elk. These include forests that provide security and latematuring forage as well as seral communities that provide forage throughout the year. We suggest that winter range may also be limiting, but diversity of summer and fall forage should be considered in management plans.

\section{Literature Cited}

Alldredge, M. W. 1999. Elk habitat relationships on an industrial forest in northern Idaho. M. S. Thesis, Univ. of Idaho, Moscow, Ida.

Alldredge, M.W., J. M. Peek, and W.A.Wall. 2001. Shrub community development and annual trends over a 100 year period on an industrial forest of Idaho. Forest Ecol. and Manage. 152:259-273.

Anderson, K. A. 1996. Micro-digestion and ICP-AES analysis for the determination of macro and micro elements in plant tissues. Atomic Spectroscopy 1:30-33.

Association of Official Analytical Chemists (A.O.A.C.). 1984. Official methods of analysis. $14^{\text {th }}$ ed. Assoc. of Official Chemists, Washington D.C.
Beaver, D. E. 1999. Habitat use and patch selection by mule deer in a sagebrush-steppe environment of southeast Idaho. M. S. Thesis, Univ. of Idaho, Moscow, Ida.

Biggins, D. E. 1975. Seasonal habitat relationships and movements of the Spotted Bear elk herd. M. S. Thesis, Univ. of Montana, Missoula, Mont.

Blair, R. M. and E. A. Epps, Jr. 1967. Distribution of protein and phosphorus in spring growth of rusty blackhaw. J. Wildl. Manage. 31:188-190.

Cameron, R. D. 1994. Reproductive pauses by female caribou. J. Mammal.75:10-13.

Collins, W. B. and P. J. Urness. 1983. Feeding behavior and habitat selection of mule deer and elk on northern Utah summer range. J. Wildl. Manage. 47:646-663.

Collins, W. B., P. J. Urness, and D. D. Austin. 1978. Elk diets and activities on different lodgepole pine habitat segments. J. Wildl. Manage. 42:799-810.

Cook, R. A. 2000. Nutritional influences on breeding dynamics in elk. M.S. Thesis, Univ. of Idaho, Moscow, Ida.

Cook, J. G. In press. Nutrition and food habits. pp 000-000 In D. E. Toweill and J. W. Thomas, (ed.), Elk of North America: Ecology and Management. $2^{\text {nd }}$ ed. Smithsonian Inst. Press, Washington, D.C..

Cook, J. G., L. J. Quinlan, L. L. Irwin, L. D. Bryant, R. A. Riggs, and J. W. Thomas. 1996. Nutrition-growth relations of elk calves during late summer and fall. J. Wildl. Manage. 60:528-541.

Cooper, S.V., K.E. Neiman, R. Steele, and D.W. Roberts. 1987. Forest habitat types of northern Idaho: a second approximation. U.S. D. A. For. Ser. Gen. Tech. Rep. INT 2136.

Crookston, N.L. and A. R. Stage. 1999. Percent canopy cover and stand structure statistics from the forests vegetation simulator. USDA For. Ser. Gen. Tech. Rep RM/RS GTR 24.

Daubenmire, R. and J. B. Daubenmire. 1968. Forest vegetation of eastern Washington and northern Idaho. Wash. State Univ. Agr. Expt. Sta. Tech. Bull.60. Pullman, Wash.

Dietz, D. R. 1972. Nutritive value of shrubs. pp 289-302 In C. M. McKell, J. P. Blaisdell, and J. R. Goodin, (ed.), Wildland Shrubs - their biology and utilization. USDA For. Serv. Gen. Tech. Rep. INT-I.

Edge, W. D., C. L. Marcum, and S. L. OlsonEdge. 1988. Summer forage and feeding site selection by elk. J. Wildl. Manage. 52:573-577.

Everitt, J. H. and C. L. Gonzalez. 1981. Seasonal nutrient content in food plants of white-tailed deer on the south Texas plains. J. Range Manage. 34:506-510.

Gratson, M. W., and Zager, P. 1999. Study IV: Factors influencing elk calf recruitment. Idaho Dept. of Fish and Game, Project W160-R-25, Subproject 31. Job progress report. Boise, Ida.

Hanley, T. A., C. T. Robbins, and D. E. Spalinger. 1989. Forest habitats and the nutritional ecology of Sitka black-tailed deer: A research synthesis with implications for forest management. USDA For. Ser. Gen. Tech. Rep. PNW-GTR-230.
Hansen, H. J., R. C. Martin, and G. A. Meuleman. 1989. Phase II, wildlife protection, mitigation, and enhancement planning, Dworshak Reservoir. Contract, DI-I7988BP92631, Draft report, Idaho Dept. Fish and Game, Boise, Ida.

Hash, H. S. 1973. Movements and food habits of Lochsa elk. M. S. Thesis, University of Idaho, Moscow, Ida.

Hershey, T.J. and T.A. Leege. 1984. Elk movements and habitat use on a managed forest in northcentral Idaho. Idaho Dept. of Fish \& Game Wildl. Bull. 10.

Hobbs, N. T., D. L. Baker, J. E. Ellis, and D. M. Swift. 1981. Composition and quality of elk winter diets in Colorado. J. Wildl. Manage. 45:156-171.

Hobbs, N. T., D. L. Baker, J. E. Ellis, D. M. Swift, and R. A. Green. 1982. Energy and nitrogen based estimates of elk winter range carrying capacity. J. Wildl. Manage. 46:12-21.

Hurley, M. A. 1994. Summer-fall ecology of the Blackfoot-Clearwater elk herd of western Montana. M. S. Thesis, Univ. of Idaho, Moscow, Ida.

Idaho Dept. Fish and Game. 1999. Statewide surveys and inventory. Federal Aid in Wildl. Restoration Project, W-170-R-22 progress report. Boise, Ida.

Irwin, L.L., and J. M. Peek. 1979. Shrub production and biomass trends following five logging treatments within the cedar-hemlock zone of northern Idaho. Forest Sci. 25:415-426.

Irwin, L.L., and J. M. Peek. 1983a. Elk, Cervus elaphus, foraging related to forest management and succession in Idaho. Canad. Field-Nat. 97(4): 443-447.

Irwin, L.L., and J. M. Peek. 1983b. Elk habitat use relative to forest succession in Idaho. J. Wildl. Manage. 47:664-672.

Kingery, J. L., J. C. Mosley, and K. C. Bordwell. 1996. Dietary overlap among cattle and cervids in northern Idaho forests. J. Range Manage. 49:8-15.

Leege, T.A. 1969. Burning seral brush ranges for big game in northern Idaho. Proc. North Amer. Wildl. and Nat. Res. Conf. 34: 429-438.

Leege, T. A. 1984. Guidelines for evaluating and managing summer elk habitat in northern Idaho. Idaho Dept. Fish and Game Wildl. Bull. 11. Boise, Ida.

Leege, T. A. and G. Godbolt. 1985. Herbaceous response following prescribed burning and seeding of elk range in Idaho. Northwest Sci. 59:134-143.

Lyon, L. J. and C. E. Jensen. 1980. Management implications of elk and deer use of clear-cuts in Montana. J. Wildl. Manage. 44:352-362.

Martinka, C. J. 1969. Population ecology of summer resident elk in Jackson Hole, Wyoming. J. Wildl. Manage. 33:465-481.

McGeehan, S. L. and D. V. Naylor. 1988. Automated instrumental analysis of carbon and nitrogen in plant and soil samples. Comm. in Soil Sci. and Plant Anal. 19:493-505. 
McLean, S. 1972. Movements and migrations of the Lochsa elk herd. M. S. Thesis, Univ. Idaho, Moscow, Ida.

Meyer, M. W., R. D. Brown, and M. W. Graham. 1984. Protein and energy content of white-tailed deer diets in the Texas coastal bend. J. Wildl.Manage. 48:527-534.

Moeur, M. 1985. COVER: a user's guide to the Canopy and SHRUBS extension of the Stand Prognosis Model. USDA For. Ser. Gen. Tech. Rep. INT-GTR- 190.

Morgantini, L. E., and R. J. Hudson. 1980. Human disturbance and habitat selection in elk. pp 132-139 In: M. S. Boyce and L. D. Hayden-Wing, (ed.), North American elk: ecology, behavior and management. Univ. Wyoming. Laramie, Wyo.

National Research Council. 1996. Nutrient requirements of cattle. Seventh edition, National Academy Press, Washington D. C.

Nelson J.R, and T.A Leege. 1982. Nutritional requirements and food habits. pp 219-277 In: J. W. Thomas and D. E. Toweill, (ed.), Elk of North America: ecology and management. Stackpole Books, Harrisburg, Penn.

Otsyina, R., C. M. McKell, and G. Van Epps. 1982. Use of range shrubs to meet nutrient requirements of sheep grazing on crested wheatgrass during fall and early winter. J. Range Manage. 35:751-753.

Parker, K. L., M. P. Gillingham, T. A. Hanley, and C. T. Robbins. 1999. Energy and protein balance of free-ranging blacktailed deer in natural forest environment. Wildl. Monogr. 163.

Patton, D. R. 1974. Patch cutting increases deer and elk use of a pine forest in Arizona. J. Forest. 72:764-766.

Pearson, H. A. 1970. Digestibility trials: in vitro techniques. pp 85-92 In $\mathrm{H}$. A. Paulsen, Jr., E. H. Reid, and K. W. Parker, (ed.), Range and wildlife habitat evaluation-a research symposium. USDA For. Serv. Misc. Publ. 1147.

Poole, S. C., V. R. Bohman, and J. A. Young. 1989. Review of selenium in soils, plants, and animals in Nevada. Great Basin Nat. 49:201-213.

Riggs, R. A., J. G. Cook, L. L. Irwin, and J. L. Spicer. 1990. Relating timber management to cover for big game on interior northwest winter range: some thoughts on reducing conflict. pp 18-36 In: R. L. Callas, D. B Kock, and E. R. Loft, (ed.), Proc. Western States and Provinces Elk Workshop. Calif Dept. of Fish and Game, Sacramento, Calif.

Robbins, C. T. 1983. Wildlife feeding and nutrition. Academic Press, Inc., Orlando, Fla.

Schoen, J. W. 1977. The ecological distribution and biology of wapiti (Cervus elaphus nelsoni) in the Cedar River Watershed, Washington. Ph.D. Diss., Univ. Washington, Seattle, Wash.

Short, H. L. 1981. Nutrition and metabolism. pp 99-127 In O. C. Wallmo, (ed.), Mule and black-tailed deer of North America. Univ. Nebraska Press, Lincoln, Neb.

Stage, A. R. 1973. Prognosis model for stand development. USDA For. Ser. Res. Pap. INT 137.
Stehn, T. 1973. Daily movements and activities of cow elk in the Sapphire Mountains of western Montana during summer and fall. M. S. Thesis, Univ. Montana, Missoula, Mont.

Stussy, R. 1993. The effects of forage improvement practices on Roosevelt elk in the Oregon Coast range. M.S. Thesis, Oregon State Univ., Corvallis, Ore.

Thomas, J. W., H. Black, Jr., R. J. Scherzinger, and R. J. Pedersen. 1979. Deer and elk. pp104-127, In J. W. Thomas (ed.), Wildlife habitats in managed forests the Blue Mountains of Oregon and Washington. USDA For. Ser., Agr. Handb. No. 553.

Thorne, E. T., R. E. Dean, and W. G. Hepworth. 1976. Nutrition during gestation in relation to successful reproduction in elk. J. Wildl. Manage. 40:330-335.

Tilley, J. M. A., and R. A. Terry. 1963. A two-stage technique for the in vitro digestion of forage crops. J. British Grassl. Soc. 18:104-111.

Trainer, C. E. 1971. The relationship of physical condition and fertility of female Roosevelt elk (Cervus canadensis roosevelti) in Oregon. M.S. Thesis, Oregon State Univ., Corvallis, Ore.

Underwood, E. J. 1977. Trace elements in human and animal nutrition. Fourth ed. Academ. Press, New York.

Unsworth, J. W. and L. Kuck. 1991. Bull elk vulnerability in the Clearwater Drainage of north-central Idaho. pp 85-88 in A. G. Christensen, L. J. Lyon, and T. N. Lonner, compilers. Proc. of the elk vulnerability symposium. Montana State Univ., Bozeman, Mont.

Unsworth, J.W., L. Kuck, E. O. Garton, and G. R. Butterfield. 1998. Elk habitat selection on the Clearwater National Forest, Idaho. J. Wildl. Manage. 62:1255-1263.

Urness, P. J., D. D. Austin, and L. C. Fierro. 1983. Nutritional value of crested wheatgrass for wintering mule deer. J. Range Manage. 36:225-226.

Van Soest, P. J. 1994. Nutritional ecology of the ruminant. Second edition. Cornell University Press, Ithaca, N.Y.

Verme, L. J. 1969. Reproductive patterns of white-tailed deer related to nutritional plane. J. Wildl. Manage. 33:881-887.

Weeks, H. P. Jr. and C. M. Kirkpatrick. 1976. Adaptations of white-tailed deer to naturally occurring sodium deficiencies. J. Wildl. Manage. 40:610-625.

Wickstrom, M. L., C. T. Robbins, T. A. Hanley, D. E. Spalinger, and S. M. Parish. 1984. Food intake and foraging energetics of elk and mule deer. J. Wildl. Manage. 48:1285-1301.

Wisdom, M. J. and J. G. Cook. 2000. North American elk. pp 694-735 In: S. Demarais and P. R. Krausman, (ed.), Ecology and management of large mammals in North America. Prentice-Hall, Upper Saddle River, N.J.

Wolf, D.D. and E.W. Carson. 1973 Respiration during drying of alfalfa herbage. Crop Sci. 13. 660.
Young, V.A. and W.L. Robinette. 1939. A study of the range habits of elk on the Selway game Preserve. Univ. Idaho School of Forest. Bull. No. 9. 